Article

\title{
Trade-Offs between Drought Survival and Rooting Strategy of Two South American Mediterranean Tree Species: Implications for Dryland Forests Restoration
}

\author{
Juan F. Ovalle ${ }^{1}$, Eduardo C. Arellano ${ }^{1,2, *}$ and Rosanna Ginocchio ${ }^{1,2}$ \\ 1 Center of Applied Ecology \& Sustainability, Avenida Libertador Bernardo O'Higgins 340, \\ Santiago 8320000, Chile; E-Mails: jrovalle@uc.cl (J.F.O.); rginocch@uc.cl (R.G.) \\ 2 Departamento de Ecosistemas y Medio Ambiente, Facultad de Agronomía e Ingeniería Forestal, \\ Pontificia Universidad Católica de Chile, Avenida Vicuña Mackenna 4860, Santiago 8320000, Chile \\ * Author to whom correspondence should be addressed; E-Mail: eduardoarellano@uc.cl; \\ Tel.: +56-2-2354-1216.
}

Academic Editors: M. Altaf Arain and Eric J. Jokela

Received: 18 August 2015 / Accepted: 10 October 2015 / Published: 15 October 2015

\begin{abstract}
Differences in water-acquisition strategies of tree root systems can determine the capacity to survive under severe drought. We evaluate the effects of field water shortage on early survival, growth and root morphological variables of two South American Mediterranean tree species with different rooting strategies during two growing seasons. One year-old Quillaja saponaria (deep-rooted) and Cryptocarya alba (shallow-rooted) seedlings were established under two watering treatments $\left(2 \mathrm{~L} \cdot \mathrm{week}^{-1} \cdot \mathrm{plant}^{-1}\right.$ and no water) in a complete randomized design. Watering improved the final survival of both species, but the increase was only significantly higher for the shallow-rooted species. The survival rates of deep- and shallow-rooted species was $100 \%$ and $71 \%$ with watering treatment, and $96 \%$ and $10 \%$ for the unwatered treatment, respectively. Root morphological variables of deep-rooted species such as surface area, volume, and diameter were higher under unwatered treatment. On the other hand, shallow-rooted species had a higher total root dry mass, length, surface area with watering treatments. Our findings suggest that deep-rooted species are highly recommended for reforestation in dry conditions, even under low soil water availability. Water supplements during the summer season can attenuate the differences between deep- and shallow-rooted species in their ability to survive drought during the early stage.
\end{abstract}


Keywords: water-acquisition strategies; root architecture; drought tolerance; field survival; dryland restoration

\section{Introduction}

Summer drought is one of the main factors negatively affecting the tree survival in all Mediterranean-type ecosystems [1-4]. Several studies report mortality rates above $70 \%$ after just the first post-planting growing season [5-10]. To address the environmental limitations, Mediterranean plants develop different structural and functional strategies to resist water stress and early mortality [11-14]. Efficient carbon assimilation and water use, xylem resistance to cavitation, maintenance of photosynthetic activity, and stomatal closure are among the key mechanisms of plant adaptation to drought $[15,16]$.

A morpho-functional strategy to resist water stress that has been broadly reported in ecological studies is the rapid increase in soil exploration capacity toward the strata with the high moisture levels by allocating resources to root growth at the onset of field establishment [17-20]. Therefore, rapid and deep rooting appears to be a very important functional trait for successful first-year survival under arid and semiarid conditions [21,22]. In addition to small secondary roots, high specific root length and absorptive root surface are key attributes [23-26] that determine a greater ability to maintain high and relatively stable xylem water potential $\left(\Psi_{\mathrm{W}}\right)$ during summer drought [27-29]. In contrast, species with shallow roots are only able to take advantage of available surface water [30,31]. Generally, species with this rooting strategy have low xylem potential during summer drought [27]. Hence, rooting habits and root plasticity are two key functional components to increase survival and growth potential under drought conditions [13,19,32-34]. However, root morphological studies focused on plant quality for dryland reforestation have not given sufficient consideration to the functional significance of different rooting strategies of tree species [35-38].

Independent of the rooting ability of the species, dry soils impose serious physical limitations to root growth $[39,40]$. Soil desiccation increases resistance to soil penetration by roots, which, in turn, affects water absorption and exploration by lateral and fine roots [40-42]. The restrictions imposed by soil dryness on root growth will be even more severe with the predicted climatic changes by the end of this century of reduced rainfall and extended dry seasons in Mediterranean regions [43]. However, plant roots can respond to reduced rainfall or water shortage by increasing both root length density [44] and the size and productivity of fine roots [45], in what ultimately translates into allocating more biomass to the root system [19,24].

Because roots are highly sensitive to small changes in soil moisture and plant mortality rates increase exponentially with a decrease in rainfall, watering can encourage root growth and survival among established plants $[21,46]$. In fact, several authors have recommended applying summer water supplements in the first years after establishment [21,47,48]. In addition to watering inputs, when rainfall levels in semiarid ecosystems have been unusually high, such as rainfall levels associated with El Niño Southern Oscillation (ENSO), tree seedling survival rates have been higher than in normal years $[30,49]$. We therefore have sought to understand how changes in water availability affect the 
morpho-functional traits of species with different rooting strategies, and how these strategies contribute to sapling survival, especially a shallow-rooting strategy. In this context, the relationship between tree rooting systems and water availability can provide key information about how different planting strategies influence the success of reforestation efforts in degraded environments that experience severe drought [18].

In our study, we hypothesized that the rooting strategies (deep- and shallow-rooting) of two South American Mediterranean tree species have important implications for field performance under severe drought conditions. However, the expected differences in survival and growth rates between the two species can be attenuated through greater water availability. The objective of the study was to evaluate the effects of water shortage during the first two years of field establishment on survival, sapling growth, and root morphological responses of two South American Mediterranean species with different rooting strategies. As target species, we used Quillaja saponaria (deep-rooted) and Cryptocarya alba (shallow-rooted) saplings. Both are endemic Neotropical species widely distributed in central Chile $\left(30^{\circ} \mathrm{S}-38^{\circ} \mathrm{W}\right)$ [50] and are commonly used in active restoration plans of degraded native forests, although with high heterogeneity in growth and survival [51].

\section{Material and Methods}

\subsection{Plant Material}

Quillaja saponaria (Quillajaceae) is a drought-deciduous and shade-intolerant pioneer tree species that develops a strong tap root in natural conditions as one of its main strategies to survive long drought periods [27]. Cryptocarya alba (Lauraceae) is an evergreen and shade-tolerant late-successional species that grows in moist areas [50], and develops shallow roots [52]. Seeds of Q. saponaria and C. alba were collected in spring 2009 from the same forest located in Cuesta Zapata $\left(33^{\circ} 23^{\prime} \mathrm{S}-71^{\circ} 16^{\prime} \mathrm{W}\right)$, central Chile. Seedlings of both species were grown under operational conditions at the Pumahuida Nursery (Santiago, Chile) in $400 \mathrm{~cm}^{3}$ black polyethylene bags from January 2009 until June 2010. At the time of planting, seedlings were homogenous and showed no signs of spiraling. The potting substrate consisted of a mixture of loam soil, leaf mold and compost at a ratio of 2:1:1. Seedlings were grown under $50 \%$ shade and a regular irrigation regime to keep the soil permanently moist. Seedlings did not receive nutritional supply (fertilization) in the nursery. Foliar analysis that determined the nutritional status of seedlings at the end of the growing period in the nursery showed $1.3 \% \mathrm{~N}, 0.3 \% \mathrm{P}$ and $1.9 \% \mathrm{~K}$ for $Q$. saponaria, and $0.9 \% \mathrm{~N}, 0.4 \% \mathrm{P}$ and $1.3 \% \mathrm{~K}$ for $C$. alba. Final seedling heights were $26.4 \pm 1.3 \mathrm{~cm}(p>0.096)$ for $Q$. saponaria and $27.1 \pm 0.6 \mathrm{~cm}(p>0.871)$ for C. alba.

\subsection{Site Description}

Seedlings were carefully planted on June 2010 at the experimental station of the Pontificia Universidad Católica de Chile $\left(33^{\circ} 26^{\prime} \mathrm{S}-71^{\circ} 01^{\prime} \mathrm{W}\right.$; altitude $\left.195 \mathrm{~m}\right)$, located in Curacaví Valley, central Chile. The soil was neutral $(6.85 \mathrm{pH})$, sandy loam (72.7\% sand, $20 \%$ silt, $7.3 \%$ clay), with low electrical conductivity $\left(0.4 \mathrm{dS} \cdot \mathrm{m}^{-1}\right)$ and $1.7 \%$ organic matter content. The soil nutrient composition was $93 \mathrm{mg} \cdot \mathrm{kg}^{-1} \mathrm{P}_{2} \mathrm{O}_{5}$ and $153 \mathrm{mg} \cdot \mathrm{kg}^{-1} \mathrm{~K}_{2} \mathrm{O}$ and was determined by wet-ashing techniques [53] on 
composite soil samples from five points within the study plot that were dried in an oven at $65{ }^{\circ} \mathrm{C}$ for $48 \mathrm{~h}$. Chemical analysis of the water used to irrigate plants showed $\mathrm{pH} 7.28,1.42 \mathrm{dS} \cdot \mathrm{m}^{-1}$ electrical conductivity and $4.14 \mathrm{meq} \cdot \mathrm{L}^{-1} \mathrm{HCO}_{3}, 21.2 \mathrm{mg} \cdot \mathrm{L}^{-1} \mathrm{~N}-\mathrm{NH}_{4}, 1.3 \mathrm{mg} \cdot \mathrm{L}^{-1} \mathrm{~N}-\mathrm{NO}_{3}$.

The climate of the study site is Mediterranean, with a 6-8 month dry period and marked rainfall seasonality, with mean annual temperatures of $15{ }^{\circ} \mathrm{C}$, mean annual rainfall of $330 \mathrm{~mm}$, and $67 \%$ relative humidity [54]. During the study period, the drought seasons lasted four months in the first year (2010-2011) and seven months in the second (2011-2012) (Figure 1).

The site was fenced and cleared to avoid herbivore damage and competing vegetation. Seedlings were shovel-planted $1.5 \mathrm{~m} \times 2.0 \mathrm{~m}$ apart. Field conditions were homogeneous in luminosity, temperature, slope and airflow. To overcome transplant shock all plants were watered regularly (2 L $\cdot$ plant $^{-1} \cdot$ week $^{-1}$ ) for 90 days (June to August 2010). To minimize the loss of thin roots and to facilitate the whole plant extraction, each plant was placed in a permeable bag that was deep enough to avoid root damage or deformation $(0.4 \mathrm{~m}$ wide $\times 0.7 \mathrm{~cm}$ long). The bag is biodegradable and made of highly water-permeable polyethylene material. At the time of final plant harvest, there was no sign of root damage or limitation that could be attributing to the bag.

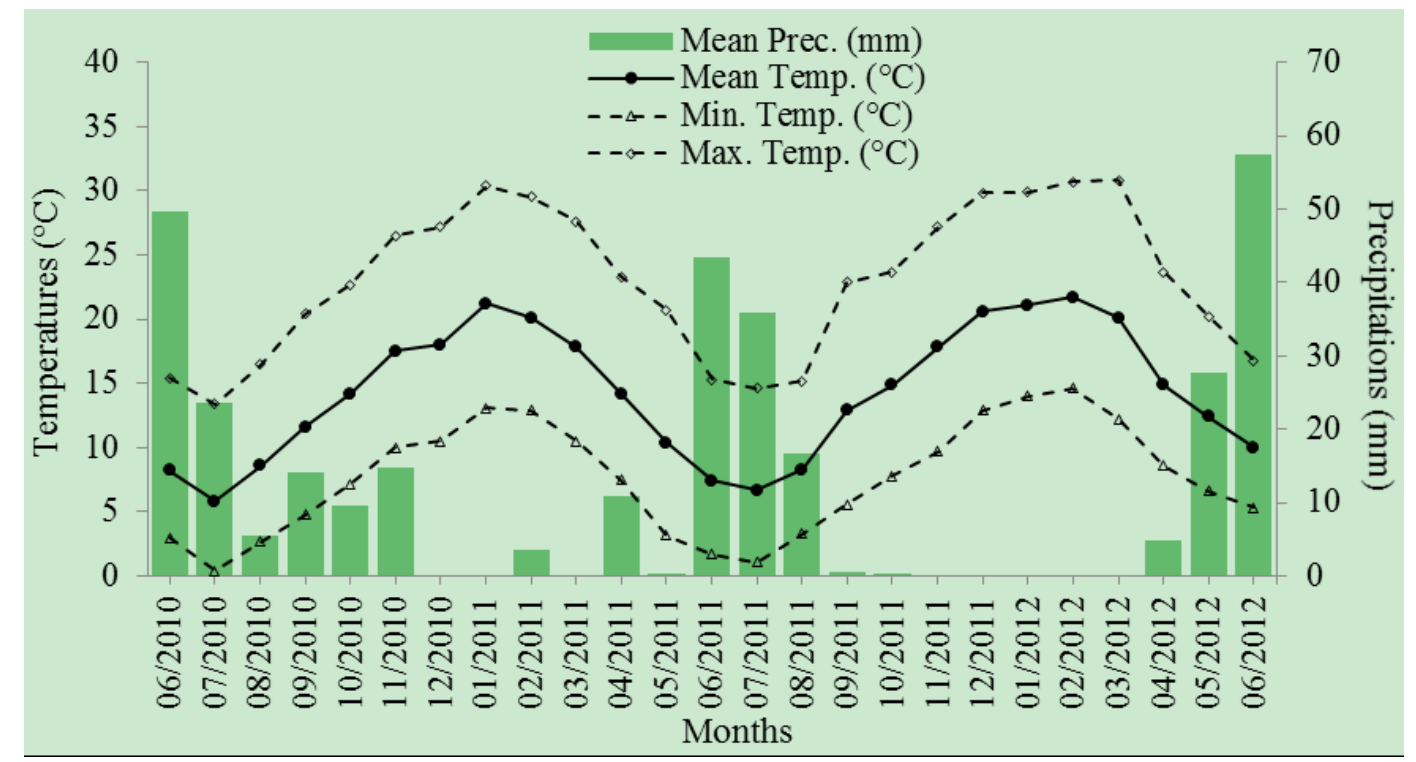

Figure 1. Monthly temperature (mean, minimum and maximum) (lines) and mean precipitation (bars) during the period of field establishment (2010-2012) (Source: Estación Pudahuel, Dirección Meteorológica de Chile).

\subsection{Experimental Design and Watering Treatments}

The experiment consisted of a completely randomized design with two watering treatments: $2 \mathrm{~L} \cdot$ plant $^{-1} \cdot$ week $^{-1}(\mathrm{~W}+)$ and no water $(\mathrm{W}-)$ for each species independently. Each treatment was applied to 48 replicates per species (96 plants in total per species). Each individual sapling was treated as a replicate for the purpose of the statistical analyses. The water treatment correspond to a common operational practice use in reforestation plans during the first growing season in semiarid conditions [55]. For $\mathrm{W}^{-}$, it was not possible to control the water received from rain or fog during the dry season, although these contributions were negligible due to severe seasonal drought (Figure 1). 


\subsection{Sampling and Measurements}

During two growing seasons (June 2010 to June 2012), random samples of 25 individuals of each treatment and species were used to periodically measure shoot height $(\mathrm{cm})$ and collar diameter $(\mathrm{mm})$. Survival (\%) was assessed every three months during the two growing seasons, considering all saplings of the two treatments and species. Saplings were considered dead when their shoots were dry and brittle, and had no green leaves. At the end of the study (June 2012), a random sample of 15 individuals of each treatment and species were completely harvested. Individuals were removed from the ground carefully pulled out the permeable bag. In general, the whole root system remained into the bags. Only in five of the deep-rooted species, the roots penetrated beyond the basal depth of bags. Roots were washed with a fine mesh sieve to remove soil while retaining thin roots. Saplings were divided into shoot and roots by cutting at the cotyledon scar and subsequently measuring shoot dry mass $(\mathrm{g})$, root dry mass $(\mathrm{g})$, the shoot/root ratio $\left(\mathrm{g} \cdot \mathrm{g}^{-1}\right)$, total root length $(\mathrm{m})$, root volume $\left(\mathrm{cm}^{3}\right)$, root surface area $\left(\mathrm{cm}^{2}\right)$ and root diameter $(\mathrm{mm})$. Dry mass was obtained by forced air oven drying at $65{ }^{\circ} \mathrm{C}$ until reaching a constant weight. The shoot/root ratio was estimated as the quotient between shoot dry mass and root dry mass. Roots were grouped according to their diameter as thin $(<1 \mathrm{~mm})$, medium $(1-2 \mathrm{~mm})$ and thick $(>2 \mathrm{~mm})$. Growth of below and aboveground components was evaluated using the absolute difference between the initial and final measurement dates. The root morphological variables of the two species were quantified by high-resolution scanner (1200 DPI resolution, Epson Perfection 4490 Scanner, USA) and image analysis software (WinRHIZO-Regent Instruments Inc., Quebec, QC, Canada).

\subsection{Statistical Analysis}

The effect of water availability on survival was analyzed for each species at every year by a Chi-square test based on the Kaplan-Meier procedure with a log-rank (Mantel-Cox) survival curve test. The effects of water availability on morphological variables were analyzed with the Student's $t$-test $(p<0.05)$ as no repeated-measures were available (randomly collected data at each sampling date). Because of the high mortality showed by the shallow-rooted species under the $\mathrm{W}$ - treatment, and the consequent imbalance in the sample size, the Bootstrap re-sampling procedure was used with 25 iterations for the original sample of morphological variables [56]. In the absence of other information about distribution, the Bootstrap procedure ensures that the sample contains all available information about the underlying distribution [56]. All statistical analyses were carried out using the SPSS v 17.0 program (SPSS Inc., Chicago, IL, USA).

\section{Results}

There were substantial differences in the survival rates between deep- and shallow-rooted species, independent of the water availability treatments (Figure 2). There was no significant difference in the survival rates of deep-rooted species according to the water availability treatments at the end of second growing season $\left(X^{2}=1.231, p=0.341\right)$, with survival rates of $100 \%$ and $96 \%$ for the $\mathrm{W}+$ and $\mathrm{W}-$ treatments, respectively. This species showed significant effects of the water availability treatments in terms of total root length, root surface area, root volume, root diameter, thin root dry mass $(p=0.013)$, 
shoot dry mass and the shoot/root ratio at the end of second growing season (Table 1). Saplings of the deep-rooted species showed no significant differences for collar diameter at the different evaluation dates and at the final of study period $(p=0.188)$, except in December $2011(p=0.06$; Figure 3a). As well, there were no significant differences in shoot height $(p=0.252$; Figure $3 b)$ and total root dry mass (Table 1) at the final of the second growing season. Shoot dry mass, thin root dry mass (Figure 4b), shoot/root ratio (Figure 5) and total root length (Table 1) were higher with the $\mathrm{W}+$ treatment than with the $\mathrm{W}$ - treatment. Root surface area, root volume and root diameter were higher with the $\mathrm{W}-$ treatment than with the $\mathrm{W}+$ treatment (Table 1).

Table 1. Estimated means \pm SE $(n=15)$ of a set of morphological variables measured in deep-rooted ( $Q$. saponaria) and shallow-rooted (C. alba) saplings under different water availability treatments $\left(\mathrm{W}+\right.$ and $\mathrm{W}^{-}$) after two years post-planting (from June 2010 to June 2012). Values with different letters indicate significant differences at $p<0.05$ derived from Student's $t$-tests.

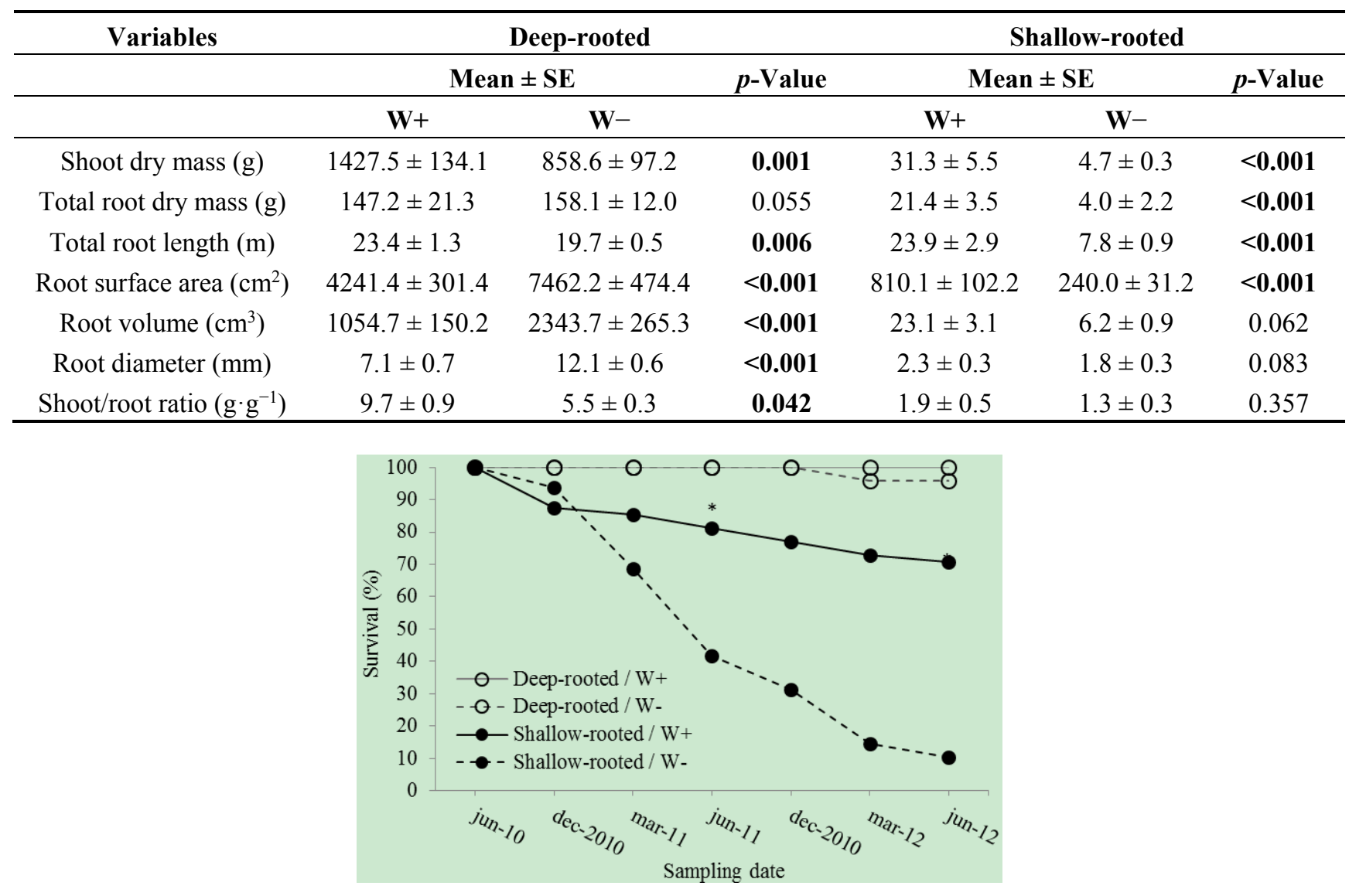

Figure 2. Survival (\%) of deep-rooted (Q. saponaria, white circles) and shallow-rooted (C. alba, black circles) species growing in the field under different water availability treatments ( $\mathrm{W}+$ : solid line; $\mathrm{W}-$ : dashed line). Each point is the percentage of saplings remaining alive out of 48 planted initially in June 2010 (Deep-rooted species $\mathrm{W}+$ and $\mathrm{W}-$ : final $n=48$ and 46 saplings, respectively; Shallow-rooted species $\mathrm{W}+$ and $\mathrm{W}-$ : final $n=34$ and 5 saplings, respectively). Asterisks indicate significant statistical differences at $p<0.05$ (Chi-Square test) between $\mathrm{W}+$ and $\mathrm{W}-$ treatments of saplings with the shallow-rooted strategy. 


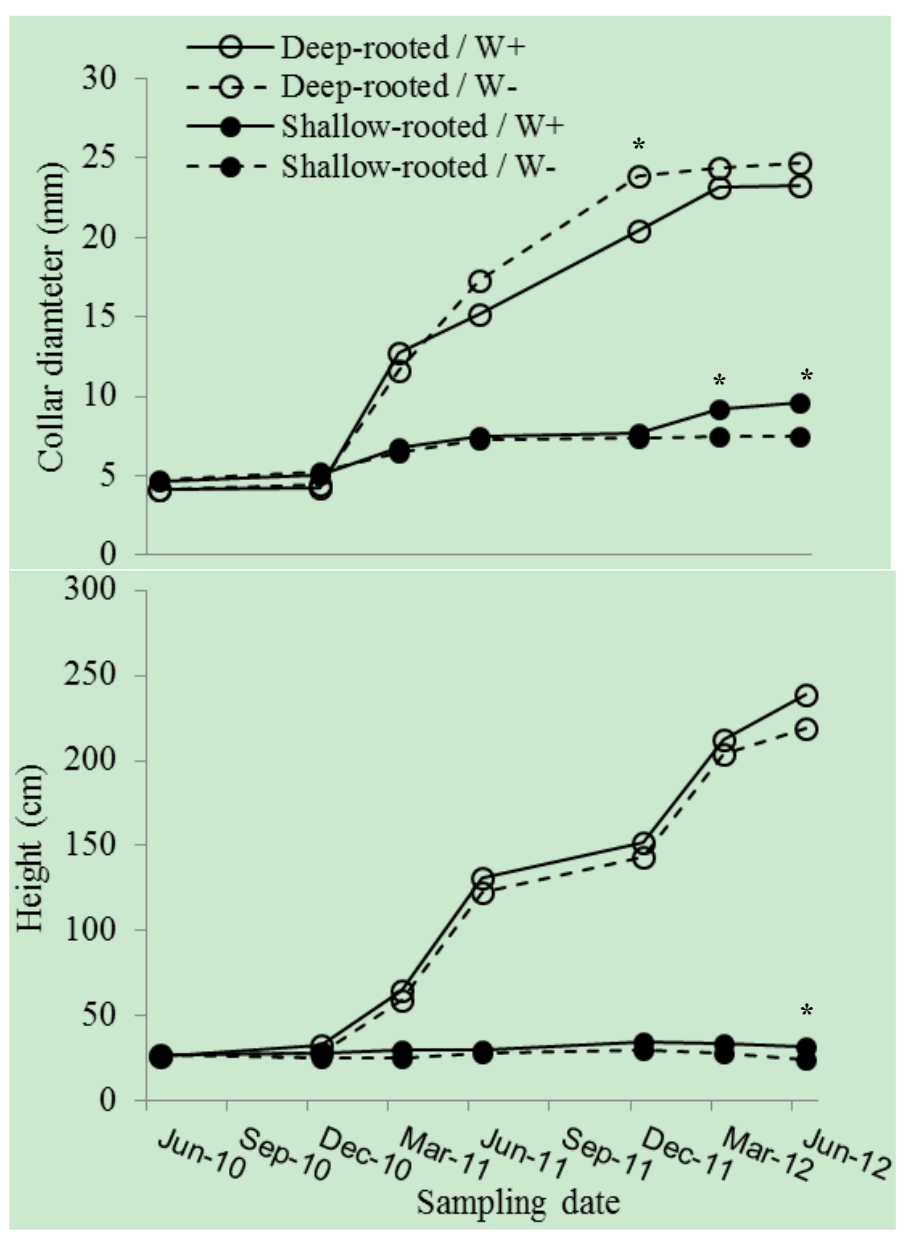

Figure 3. Mean values $\pm \mathrm{SE}$ of (a) collar diameter $(\mathrm{mm})$ and $(\mathbf{b})$ shoot height $(\mathrm{cm})$ of deep-rooted ( $Q$. saponaria, white circles) and shallow-rooted ( $C$. alba, black circles) saplings growing in the field under different water availability treatments $(\mathrm{W}+$ : solid line; W-: dashed line). Data were obtained during two growing seasons, specifically in June 2010, December 2010, March 2011, June 2011, December 2011, March 2012, and June 2012. Asterisks indicate significant differences at $p<0.05$ (Student's $t$-test).

In contrast, the survival rates of the shallow-rooted species varied with the water availability treatments in the first $\left(X^{2}=12.962, p<0.001\right)$ and second growing seasons $\left(X^{2}=32.941, p<0.001\right)$ (Figure 2). The survival rate with the $\mathrm{W}+$ treatment was over $80 \%$ after the first dry period (June 2011), while it was only $42 \%$ with the $\mathrm{W}$ - treatment for the same period. The differences in survival rates between the two treatments were more pronounced after the second drought season (June 2012), with $70.83 \%$ versus $10.4 \%$ survival with the $\mathrm{W}+$ and $\mathrm{W}-$ treatments, respectively (Figure 2). Saplings of the shallow-rooted species showed significant effects of the water availability treatments on collar diameter $(p=0.004)$, shoot height $(p<0.001)$, total root length, root surface area, total root dry mass, thin root dry mass $(p<0.001)$, shoot dry mass and survival at the final of the second growing season (Table 1). In particular, statistically significant differences in collar diameter and shoot height were observed only in the last two (March and June 2012) and the last (June 2012) evaluation dates, respectively. At the end of the second growing season, there were no significant differences in the shoot/root ratio (Figure 5), root volume and root diameter (Table 1). The difference between initial and final height (height increase) was not significant (1.2 cm; $p=0.219$; Figure $3 b)$. Collar diameter, 
shoot height (Figure 3a,b), and shoot dry mass, total root dry mass, thin root dry mass (Figure 4a,b), total root length and root surface area (Table 1) were higher with the $\mathrm{W}+$ treatment.

With respect to total root dry mass, saplings of the shallow-rooted species allocated more biomass to thin roots $(41.8 \%)$ than saplings with the deep-rooted strategy $(3.6 \%)$. The latter showed a marked capacity to allocate biomass to thick roots, which represented $89.27 \%$ of total root dry mass (Figure 4a).
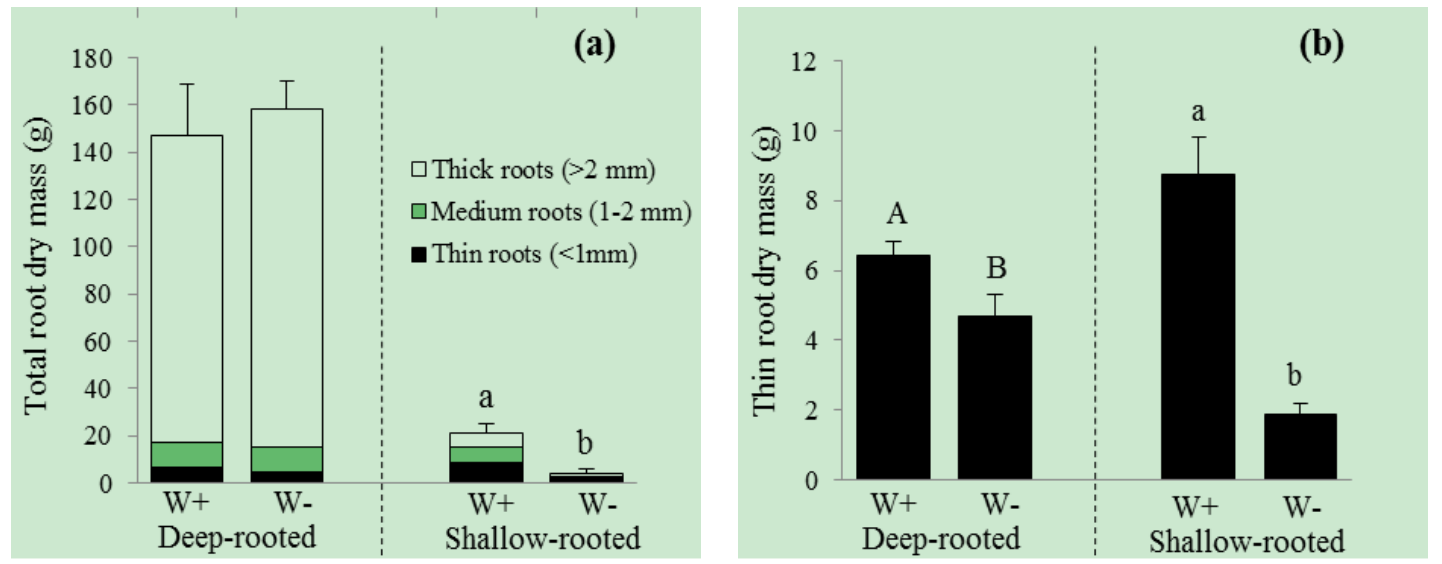

Figure 4. Mean values $\pm \mathrm{SE}$ of (a) total root dry mass (g) and (b) thin root dry mass (g) of deep-rooted and shallow-rooted saplings grown in the field under different water availability treatments $(\mathrm{W}+$ and $\mathrm{W}-$ ). Data were obtained at the end of the second growing season (June 2012). Means with different letters indicate significant differences at $p<0.05$ (Student's $t$-test).

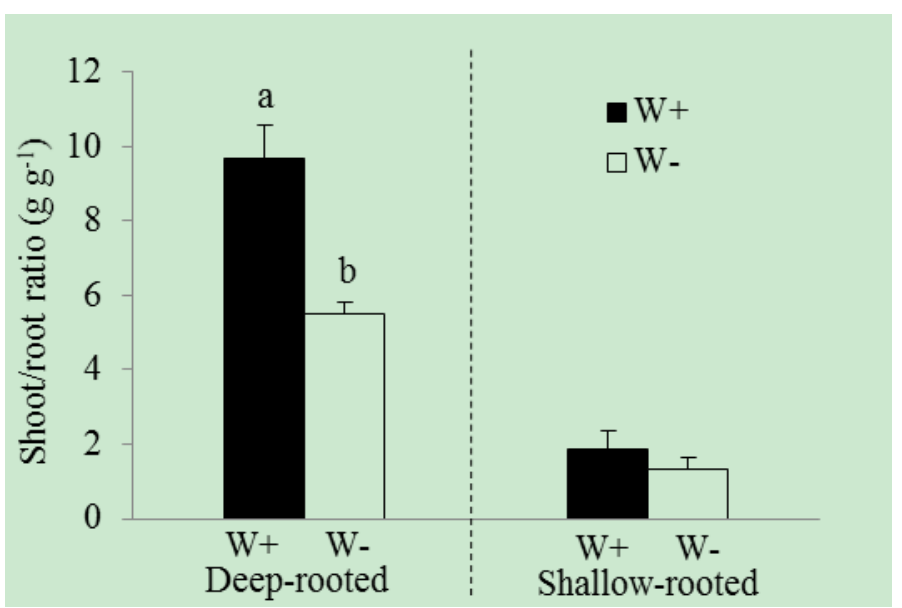

Figure 5. Mean values $\pm \mathrm{SE}$ of shoot/root ration $\left(\mathrm{g} \cdot \mathrm{g}^{-1}\right)$ of deep-rooted and shallow-rooted saplings growing in the field under different water availability treatments $(\mathrm{W}+$ and $\mathrm{W}-$ ). Data were obtained at the end of the second growing season (June 2012). Means with different letters indicate significant differences at $p<0.05$ (Student's $t$-test).

\section{Discussion}

Increased water availability positively affects sapling survival and growth for both deep-rooted and shallow-rooted species. As demonstrated in other studies, watering can increase survival and improve 
root growth during the establishment period, particularly when water supplements are applied during the summer season in semiarid environment [21,47,48,51,57]. However, our findings suggest that differences in water-acquisition strategies of root systems of South American Mediterranean tree species determine different capacity to survive under situations of severe drought.

The deep-rooted and drought tolerant species ( $Q$. saponaria) had a high survival rate, independent of water availability, indicating the high degree of flexibility of this species to resist drought conditions [27,58]. Several studies of plants in Mediterranean ecosystems around the world confirm that deep-rooted species perform well with low water availability [13,18,27,32], although some studies have reported survival in the range of $0 \%$ to $30 \%$ after extremely dry periods $[6,8,10]$.

The shallow-rooted and less drought tolerant species (C. alba) [27,52] had different survival rates depending on water availability. The difference in survival rates was more pronounced by the end of the second growing season, with $70 \%$ survival for saplings under the watering treatment, while saplings under the water shortage treatment suffered a sharp and continuing rise in mortality rates until the end of the study period, even during the rainy season. Water availability had a positive effect on the collar diameter and shoot growth of the shallow-rooted species, however there was practically no shoot growth between June 2010 and June 2012.

The strategies of the two species are reflected in shoot and root biomass allocation. Under severe drought conditions, the species with the deep-rooting strategy showed a rapid and drastic decrease in aboveground biomass by about $43 \%$. This could be attributed to the early foliar abscission, proper of drought-deciduous species, and thicker roots development under water shortage [59]. This response is consistent with the optimal resource partitioning theory, which predicts that plants increase the ratio between water absorbing and transpiring surfaces in response to water shortage [60]. In contrast, the shallow-rooted species did not significantly alter its balance of biomass as a function of water availability. Similar results were found by Donoso et al. [58] under semi-controlled conditions, where there was a significant reduction in the shoot/root ratio of $Q$. saponaria (2.3 to 1.4), and no significant change in C. alba (1.3).

The success of deep-rooted Mediterranean forest species to survive dry conditions is in part due to their ability to develop a greater volume of thick roots responsible for colonizing moister soil strata [18,20]. Padilla et al. [24] also suggests that a key role is higher specific root length to resist water stress. In our study, the deep-rooted species increased all root morphology variables under water shortage with the exception of thin root dry mass. A similar tendency was observed in a semiarid shrub species, where the root system showed higher total root length density in response to a $30 \%$ reduction in annual rainfall (controlled conditions) [44].

The shallow-rooting species is characterized by allocating a greater proportion of belowground biomass and concentrates the fine roots production at first $40 \mathrm{~cm}$ of soil [52]. In our study, besides finding a greater proportion of fine or thin roots in the shallow-rooted species in relation to roots of the other diametric class, we found that with higher water availability the thin roots increased considerably, and, in fact, quadrupled. Although some studies confirm the positive relationship between fine root production and water availability [46], several recent studies have found an increase in the size and density of fine roots under drought conditions [24,25]. Hernández et al. [61] suggest that fine roots improve root hydraulic conductance, and, consequently, improve water status and plant productivity under drought [22]. 
Soil conditions in semiarid environments limit the growth of fine roots. Several authors have noted that soil dryness significantly affects the capacity of fine roots to extend themselves because the high resisting penetration by the low soil matric potential [42,44,62]. For example, in a study on Fagus sylvatica L., Meier and Leuschner [63] found that the drought caused shortening of fine roots and consequently reduced specific root length.

Clear differences in shoot and root growth confirm the different ecological requirements of each species ( $Q$. saponaria and C. alba), and therefore their distinct capacities to resist drought conditions according to their rooting habits [18,20]. Recent studies suggest that there are major differences in the size and structure of the xylem networks and in physiological behavior among species with distinct root depths, resulting in different capacities to resist embolism and cavitation [14,33]. The advantages of species with deep roots are affirmed by the results of Peñuelas and Filella [28] and Armas et al. [29], who describe high $\Psi_{\mathrm{W}}$ values in dry periods in Pinus nigra Arnold and Pistacia lentiscus $\mathrm{L}$. (both with deep-rooting strategies), respectively, compared to other species with shallower roots. In addition, Giliberto and Estay [27] found a correlation between the water status of plants and rooting habits among South American Mediterranean tree species. The authors observed that species like Lithrea caustica (Mol.) H. et. A. and Q. saponaria (both highly resistant drought) had the highest and least variable $\Psi_{\mathrm{W}}$ during summer drought. These structural and functional differences may partly explain the contrasting responses of the species in our study.

For future field studies with shallow-rooted species in semiarid conditions, we suggest more than two years of evaluation to demonstrate reforestation viability [64]. Our current study highlights the importance of expanding and updating knowledge on the root morphology of species of interest for the restoration of South American Mediterranean forests, given the high species diversity in these regions [65], implying also diversity in rooting habits [32,52].

\section{Conclusions}

Differences in water acquisition strategies of tree species with deep- and shallow-rooting can determine their capacity to survive severe summer droughts. The deep-rooted species $(Q$. saponaria $)$ had the better drought performance, independent of the water availability treatment. In contrast, summer watering significantly improved the survival rate (close to $70 \%$ ) of the shallow-rooted species. Water restriction promoted greater root growth of the deep-rooted saplings, while it had the opposite effect on the shallow-rooted saplings. The shallow-rooted species prioritizes root biomass allocation to thin roots while the deep-rooted species prioritizes root biomass to thick roots. However, both species increase thin root dry mass under greater water availability. Reforestation efforts need to consider deep-rooted species in stressful areas, especially in projects with low technical and economic capacity to conduct watering in the field. However, if water availability is not a constraint for the two first years after plantation, species with a shallow-rooted strategy could be used successfully in semi-arid environments.

\section{Acknowledgments}

This study was supported by CONICYT (24121675/2012), MECESUP-UC0707, and Minera AngloAmerican Chile. We recognize the collaboration of the Vivero y Jardín Pumahuida Ltda and the 
Estación Experimental Curacaví, Facultad de Agronomía e Ingeniería Forestal, Pontificia Universidad Católica de Chile. We thank Marie Curie Actions fellowships (7th European Community Framework Programme), International Project ForEAdapt 269257, and Center of Applied Ecology \& Sustainability (CAPES UC) by CONICYT FB 0002/2014. We thank those who provided technical support in the field and laboratory work, especially Julio Calderón, Mónica Escobar, Rommy Oliva and Patricio Valenzuela.

\section{Author Contributions}

Juan F. Ovalle made the experimental design, collected the data, made the analyses and interpretation of results, and wrote the manuscript. Eduardo C. Arellano contributed to define the main lines of the experiment, interpretation of results, and co-wrote the manuscript, besides being the project advisor. Rosanna Ginocchio contributed to define the main lines of the experiment and made a critical review of manuscript.

\section{Conflict of Interest}

The authors declare no conflict of interest.

\section{References}

1. Peñuelas, J. Severe drought effects on mediterranean woody. For. Sci. 2001, 47, 214-218.

2. Vallejo, R.; Smanis, A.; Chirino, E.; Fuentes, D.; Valdecantos, A.; Vilagrosa, A. Perspectives in dryland restoration: Approaches for climate change adaptation. New For. 2012, 43, 561-579.

3. Zeppel, M.J.B.; Harrison, S.P.; Adams, H.D.; Kelley, D.I.; Li, G.; Tissue, D.T.; Dawson, T.E.; Fensham, R.; Belinda, E.; Palmer, A.; et al. Drought and resprouting plants. New Phytol. 2015, 206, 583-589.

4. Camarero, J.; Franquesa, M.; Sangüesa-Barreda, G. Timing of drought triggers distinct growth responses in Holm Oak: Implications to predict warming-induced forest defoliation and growth decline. Forests 2015, 6, 1576-1597.

5. Frazer, J.; Davis, S. Differential survival of chaparral seedlings during the first summer drought after wildfire. Oecologia 1988, 76, 215-221.

6. Holmgren, M.; Segura, A.M.; Fuentes, E.R. Limiting mechanisms in the regeneration of the Chilean matorral Experiments on seedling establishment in burned and cleared mesic sites. Plant Ecol. 2000, 147, 49-57.

7. Gómez-Aparicio, L.; Pérez-Ramos, I.M.; Mendoza, I.; Matías, L.; Quero, J.L.; Castro, J.; Zamora, R.; Marañón, T. Oak seedling survival and growth along resource gradients in Mediterranean forests: Implications for regeneration in current and future environmental scenarios. Oikos 2008, 117, 1683-1699.

8. Becerra, P.I.; González-Rodríguez, V.; Smith-Ramírez, C.; Armesto, J.J. Spatio-temporal variation in the effect of herbaceous layer on woody seedling survival in a Chilean mediterranean ecosystem. J. Veg. Sci. 2011, 22, 847-855. 
9. Benigno, S.M.; Dixon, K.W.; Stevens, J.C. Seedling mortality during biphasic drought in sandy Mediterranean soils. Funct. Plant Biol. 2014, 41, 1239-1248.

10. Morales, N.; Becerra, P.; Arellano, E.; Gilabert, H. Effect of large and small herbivores on seed and seedling survival of Beilschmiedia miersii in central Chile. Bosque (Valdivia) 2015, 36, 127-132.

11. Lo Gullo, M.A.; Salleo, S. Different strategies of drought resistance in three Mediterranean sclerophyllous trees growing in the same environmental conditions. New Phytol. 1988, 108, 267-276.

12. Valladares, F.; Sánchez-Gómez, D. Ecophysiological traits associated with drought in Mediterranean tree seedlings: Individual responses versus interspecific trends in eleven species. Plant Biol. 2006, 8, 688-697.

13. West, A.G.; Dawson, T.E.; February, E.C.; Midgley, G.F.; Bond, W.J.; Aston, T.L. Diverse functional responses to drought in a Mediterranean-type shrubland in South Africa. New Phytol. 2012, 195, 396-407.

14. Aguadé, D.; Poyatos, R.; Rosas, T.; Martínez-vilalta, J. Comparative drought responses of Quercus ilex L. and Pinus sylvestris L. in a montane forest undergoing a vegetation shift. Forests 2015, 6, 2505-2529.

15. Valladares, F.; Pearcy, R.W. Interactions between water stress, sun-shade acclimation, heat tolerance and photoinhibition in the sclerophyll Heteromeles arbutifolia. Plant Cell Environ. 1997, 20, 25-36.

16. Vilagrosa, A.; Bellot, J.; Vallejo, V.R.; Gil-Pelegrin, E. Cavitation, stomatal conductance, and leaf dieback in seedlings of two co-occurring Mediterranean shrubs during an intense drought. J. Exp. Bot. 2003, 54, 2015-2024.

17. Lloret, F.; Casanovas, C.; Peñuelas, J. Seedling survival of Mediterranean shrubland species in relation to root:shoot ratio, seed size and water and nitrogen use. Funct. Ecol. 1999, 13, 210-216.

18. Padilla, F.M.; Pugnaire, F.I. Rooting depth and soil moisture control Mediterranean woody seedling survival during drought. Funct. Ecol. 2007, 21, 489-495.

19. Markesteijn, L.; Poorter, L. Seedling root morphology and biomass allocation of 62 tropical tree species in relation to drought- and shade-tolerance. J. Ecol. 2009, 97, 311-325.

20. Paula, S.; Pausas, J.G. Root traits explain different foraging strategies between resprouting life histories. Oecologia 2011, 165, 321-331.

21. León, M.F.; Squeo, F.A.; Gutiérrez, J.R.; Holmgren, M. Rapid root extension during water pulses enhances establishment of shrub seedlings in the Atacama Desert. J. Veg. Sci. 2011, 22, 120-129.

22. Villar-Salvador, P.; Puértolas, J.; Cuesta, B.; Peñuelas, J.L.; Uscola, M.; Heredia-Guerrero, N.; Benayas, J.M.R. Increase in size and nitrogen concentration enhances seedling survival in Mediterranean plantations. Insights from an ecophysiological conceptual model of plant survival. New For. 2012, 43, 755-770.

23. Padilla, F.M.; Miranda, J.D.D.; Pugnaire, F.I. Early root growth plasticity in seedlings of three Mediterranean woody species. Plant Soil 2007, 296, 103-113.

24. Padilla, F.M.; Miranda, J.D.; Jorquera, M.J.; Pugnaire, F.I. Variability in amount and frequency of water supply affects roots but not growth of arid shrubs. Plant Ecol. 2009, 204, 261-270.

25. Comas, L.H.; Becker, S.R.; Cruz, V.M.V; Byrne, P.F.; Dierig, D. Root traits contributing to plant productivity under drought. Front. Plant Sci. 2013, 4, 1-16. 
26. Olmo, M.; Lopez-Iglesias, B.; Villar, R. Drought changes the structure and elemental composition of very fine roots in seedlings of ten woody tree species. Implications for a drier climate. Plant Soil 2014, 384, 113-129.

27. Giliberto, J.; Estay, H. Seasonal water stress in some chilean matorral shrubs. Bot. Gaz. 1978, 139, 236-240.

28. Peñuelas, J.; Filella, I. Deuterium labelling of roots provides evidence of deep water access and hydraulic lift by Pinus nigra in a Mediterranean forest of NE Spain. Environ. Exp. Bot. 2003, 49, 201-208.

29. Armas, C.; Padilla, F.M.; Pugnaire, F.I.; Jackson, R.B. Hydraulic lift and tolerance to salinity of semiarid species: Consequences for species interactions. Oecologia 2010, 162, 11-21.

30. Torres, R.; Squeo, F.; Jorquera, C.; Aguirre, E.; Ehleringer, J.R. Evaluación de la capacidad estacional de utilizar eventos de precipitación en tres especies de arbustos nativos de Chile con distintos sistemas radiculares. Rev. Chil. Hist. Nat. 2002, 75, 737-749.

31. Lynch, J.P. Steep, cheap and deep: An ideotype to optimize water and $\mathrm{N}$ acquisition by maize root systems. Ann. Bot. 2013, 112, 347-357.

32. Canadell, J.; Zedler, P. Underground structures of woody plants in Mediterranean ecosystems of Australia, California, and Chile. In Ecology and Biogeography of Mediterranean Ecosystems in Chile, California, and Australia; Arroyo, M., Zedler, P., Fox, M., Eds.; Springer: Berlin, Germany, 1995; pp. 177-210.

33. Johnson, D.M.; Brodersen, C.R.; Reed, M.; Domec, J.-C.; Jackson, R.B. Contrasting hydraulic architecture and function in deep and shallow roots of tree species from a semi-arid habitat. Ann. Bot. 2014, 113, 617-627.

34. Poorter, H.; Ryser, P. The limits to leaf and root plasticity: What is so special about specific root length? New Phytol. 2015, 206, 1188-1190.

35. Villar-Salvador, P.; Planelles, R.; Oliet, J.; Peñuelas-Rubira, J.L.; Jacobs, D.F.; González, M. Drought tolerance and transplanting performance of holm oak (Quercus ilex) seedlings after drought hardening in the nursery. Tree Physiol. 2004, 24, 1147-1155.

36. Chirino, E.; Vilagrosa, A.; Hernández, E.; Matos, A.; Vallejo, R. Effects of a deep container on morpho-functional characteristics and root colonization in Quercus suber L. seedlings for reforestation in Mediterranean climate. For. Ecol. Manag. 2008, 256, 779-785.

37. Jacobs, D.F.; Salifu, K.F.; Davis, A.S. Drought susceptibility and recovery of transplanted Quercus rubra seedlings in relation to root system morphology. Ann. For. Sci. 2009, 66, 1-12.

38. Andivia, E.; Fernández, M.; Vázquez-piqué, J. Assessing the effect of late-season fertilization on Holm oak plant quality: Insights from morpho-nutritional characterizations and water relations parameters. New For. 2014, 45, 149-163.

39. Clark, L.J.; Whalley, W.R.; Barraclough, P.B. How do roots penetrate strong soil? Plant Soil 2003, 255, 93-104.

40. Whitmore, A.P.; Whalley, W.R. Physical effects of soil drying on roots and crop growth. J. Exp. Bot. 2009, 60, 2845-2857.

41. Gaul, D.; Hertel, D.; Borken, W.; Matzner, E.; Leuschner, C. Effects of experimental drought on the fine root system of mature Norway spruce. For. Ecol. Manag. 2008, 256, 1151-1159. 
42. Bengough, G.; McKenzie, B.M.; Hallett, P.D.; Valentine, T. Root elongation, water stress, and mechanical impedance: A review of limiting stresses and beneficial root tip traits. J. Exp. Bot. 2011, 62, 59-68.

43. Stocker, T.; Qin, D.; Plattner, G.; Tignor, M.; Simon, A.; Boschung, J.; Navels, A.; Xia, Y.; Bex, V.; Migley, P. The Physical Science Basis. Working Group I Contribution to the Fifth Assessment Panel on Climate Change. Summary for Policymarkes; IPCC: Geneva, Switzerland. 2013; p. 33-115.

44. Padilla, F.; Miranda, J.D.D.; Armas, C.; Pugnaire, F. Effects of changes in rainfall amount and pattern on root dynamics in an arid shrubland. J. Arid Environ. 2015, 114, 49-53.

45. Hertel, D.; Strecker, T.; Müller-Haubold, H.; Leuschner, C. Fine root biomass and dynamics in beech forests across a precipitation gradient-Is optimal resource partitioning theory applicable to water-limited mature trees? J. Ecol. 2013, 101, 1183-1200.

46. Brunner, I.; Pannatier, E.G.; Frey, B.; Rigling, A.; Landolt, W.; Zimmermann, S.; Dobbertin, M. Morphological and physiological responses of Scots pine fine roots to water supply in a dry climatic region in Switzerland. Tree Physiol. 2009, 29, 541-550.

47. Benayas, J.M.R.; Camacho-Cruz, A. Performance of Quercus ilex saplings planted in abandoned Mediterranean cropland after long-term interruption of their management. For. Ecol. Manag. 2004, 194, 223-233.

48. Valdecantos, A.; Fuentes, D.; Smanis, A.; Llovet, J.; Morcillo, L.; Bautista, S. Effectiveness of low-cost planting techniques for improving water availability to Olea europaea seedlings in degraded drylands. Restor. Ecol. 2014, 22, 327-335.

49. Holmgren, M.; López, B.; Gutiérrez, J. Herbivory and plant growth rate determine the success of El Nino Southern Oscillation-driven tree establishment in semiarid South America. Glob. Chang. Biol. 2006, 12, 2263-2271.

50. Donoso, C. Reseña ecológica de los bosques Mediterráneos de Chile. Bosque (Valdivia) 1982, 4, 117-146.

51. Becerra, P.I.; Cruz, G.; Ríos, S.; Castelli, G. Importance of irrigation and plant size in the establishment success of different native species in a degraded ecosystem of central Chile. Bosque (Valdivia) 2013, 34, 23-24.

52. Hoffmann, A.; Kummerow, J. Root Studies in the Chilean Matorral. Oecologia 1978, 69, 57-69.

53. Pérez-Harguindeguy, N.; Garnier, E.; Lavorel, S.; Poorter, H.; Jaureguiberry, P.; Cornwell, W.K.; Craine, J.M.; Gurvich, D.E.; Urcelay, C.; Veneklaas, E.J.; et al. New handbook for standardised measurement of plant functional traits worldwide. Aust. J. Bot. 2013, 61, 167-234.

54. Di Castri, F.; Hajek, E. Bioclimatología de Chile; Di Castri, F., Hajek, E., Eds.; Vicerrectoría UC: Santiago, Chile, 1976.

55. Valenzuela, L. Evaluación de un ensayo de riego y fertilización de quillay (Quillaja saponaria Mol.) en la comuna de San Pedro, provincia de Melipilla, Región Metropolitana. Undergraduate' Thesis, Universidad de Chile, Santiago, Chile, 2007; p. 66.

56. Efron, B. Bootstrap methods: Another look at the Jackknife. Ann. Stat. 1979, 7, 1-26.

57. Ostonen, I.; Püttsepp, Ü.; Biel, C.; Alberton, O.; Bakker, M.; Lohmus, K.; Majdi, H.; Metcalfe, D.; Olsthoorn, A.; Pronk, A.; et al. Specific root length as an indicator of environmental change. Plant Biosyst. 2007, 141, 426-442. 
58. Donoso, S.; Peña, K.; Pacheco, C.; Luna, G.; Aguirre, A. Physiological and growth response in Quillaja saponaria and Cryptocarya alba plants under restricted water conditions. Bosque (Valdivia) 2011, 32, 187-195.

59. Zida, D.; Tigabu, M.; Sawadogo, L.; Odén, P.C. Initial seedling morphological characteristics and field performance of two Sudanian savanna species in relation to nursery production period and watering regimes. For. Ecol. Manag. 2008, 255, 2151-2162.

60. Bloom, A.J.; Chapin, F.S.; Mooney, H. Resource limitation in plants-An economic analogy. Ann. Rev. Ecol. Syst. 1985, 16, 363-392.

61. Hernández, E.; Vilagrosa, A.; Luis, V.C.; Llorca, M.; Chirino, E.; Vallejo, V.R. Root hydraulic conductance, gas exchange and leaf water potential in seedlings of Pistacia lentiscus L. and Quercus suber L. grown under different fertilization and light regimes. Environ. Exp. Bot. 2009, 67, 269-276.

62. Jin, K.; Shen, J.; Ashton, R.W.; White, R.P.; Dodd, I.C.; Parry, M.A.J.; Whalley, W.R. Wheat root growth responses to horizontal stratification of fertiliser in a water-limited environment. Plant Soil 2015, 386, 77-88.

63. Meier, I.C.; Leuschner, C. Genotypic variation and phenotypic plasticity in the drought response of fine roots of European beech. Tree Physiol. 2008, 28, 297-309.

64. Lo Gullo, M.; Salleo, S.; Rosso, R.; Trifilò, P. Drought resistance of 2-year-old saplings of Mediterranean forest trees in the field: Relations between water relations, hydraulics and productivity. Plant Soil 2003, 250, 259-272.

65. Cowling, R.M.; Rundel, P.W.; Lamont, B.B.; Arroyo, M.K.; Arianoutsou, M. Plant diversity in Mediterranean-climate regions. Trends Ecol. Evol. 1996, 11, 362-366.

(C) 2015 by the authors; licensee MDPI, Basel, Switzerland. This article is an open access article distributed under the terms and conditions of the Creative Commons Attribution license (http://creativecommons.org/licenses/by/4.0/). 